\title{
Gilles Banderier, Françoise Pautrard; femme et poète du premier XVII siècle
}

\section{Cecilia Torelli}

\section{(2) OpenEdition}

1 Journals

\section{Edizione digitale}

URL: https://journals.openedition.org/studifrancesi/40551

DOI: 10.4000/studifrancesi.40551

ISSN: 2421-5856

Editore

Rosenberg \& Sellier

\section{Edizione cartacea}

Data di pubblicazione: 1 juillet 2004

Paginazione: 178

ISSN: 0039-2944

Notizia bibliografica digitale

Cecilia Torelli, «Gilles Banderier, Françoise Pautrard; femme et poète du premier XVIIe siècle», Studi

Francesi [Online], 142 (XLVIII | I) | 2004, online dal 30 novembre 2015, consultato il 09 septembre 2021. URL: http://journals.openedition.org/studifrancesi/40551 ; DOI: https://doi.org/10.4000/studifrancesi. 40551

Questo documento è stato generato automaticamente il 9 septembre 2021.

\section{(c) 9 (i) $\Theta$}

Studi Francesi è distribuita con Licenza Creative Commons Attribuzione - Non commerciale - Non opere derivate 4.0 Internazionale. 


\title{
Gilles Banderier, Françoise Pautrard; femme et poète du premier XVII ${ }^{\mathrm{e}}$ siècle
}

\author{
Cecilia Torelli
}

NOTIZIA

GILLES BANDERIER, Françoise Pautrard; femme et poète du premier XVII ${ }^{\mathrm{e}}$ siècle, «XVII ${ }^{\mathrm{e}}$ siècle», n. 218, janvier-mars 2003, pp. 117-159.

Nella sezione «Notes et documents» della rivista, l'A. presenta una poetessa sconosciuta, originaria della Franca Contea, Jaqua Françoise Pautrard, autrice di poesie fino ad oggi inedite e contenute nel manoscritto 533 della biblioteca di Besançon. L'A. pubblica qui alcune delle composizioni di ispirazione morale e religiosa che ritiene essere le migliori e le più originali. 